\title{
12. MORPHOLOGY AND ALTERATION OF THE UPPER OCEANIC CRUST FROM IN-SITU ELECTRICAL EXPERIMENTS IN DSDP/ODP HOLE 504B ${ }^{1}$
}

\author{
Philippe A. Pezard and Roger N. Anderson ${ }^{2}$
}

\begin{abstract}
During ODP Leg 111, the drillship JOIDES Resolution returned to DSDP Hole 504B, on the south flank of the Costa Rica Rift. The main objective of Leg 111 was the study of the physical and chemical structure of young oceanic crust in the deepest hole yet drilled into the oceanic crust. In addition to the drilling of an additional $212.3 \mathrm{~m}$ into the massive units of Layer 2C, Leg 111 provided the opportunity to conduct an extensive suite of in-situ experiments, including the recording of a continuous electrical resistivity profile, from which total and fracture porosity estimates were computed. This allowed us to discriminate the large-scale layers of the crust, to isolate individual lithologic units (such as pillows and massive flows), and to describe the overall morphology of the upper crust.

In the extrusive part of the crust, certain massive flows ( $\geq 10 \mathrm{~m}$ thick) appear to be permeability barriers that subsequently constrain fluid circulation. We interpret the flows of Unit $2 \mathrm{D}$ as the upper limit of an underpressured aquifer located within Layer $2 \mathrm{~A}$ and Unit 27 as the boundary between low-temperature, seawater alteration facies of basalt and higher temperature alteration phases. This relationship between morphology and hydrological regime, and therefore alteration of the basaltic basement, might be viewed as related to the accretion process of the upper oceanic crust. The presence of fractures can be attributed in most cases to thermal stresses from the cooling of a nearby unit or to tectonic features such as the inferred listric fault at about $4300 \mathrm{~m}$ below rig floor ( $825 \mathrm{~m}$ below seafloor). The porosity estimate obtained from the analysis of in-situ measurements is (1) reduced in accounting for clay conduction via cation exchange mechanisms, (2) constant over long sections of the drill hole, and (3) observed to decrease by steps with increasing depth. The extremely low values of porosity computed in the dikes indicate a slow regime of hydrothermal circulation deep into the crust and correlate with the low values of in-situ permeability deduced from packer experiments.
\end{abstract}

\section{INTRODUCTION}

A main objective of Legs $69,70,83$, and 92 of the Deep Sea Drilling Project (DSDP) and Leg 111 of the Ocean Drilling Program (ODP) was the study of the physical and chemical structure of young oceanic crust through drilling Hole 504B, which is located in the eastern equatorial Pacific (Fig. 1), on the south flank of the Costa Rica Rift (Costa Rica Rift United Scientific Team, 1982; Cann, Langseth, et al., 1983; Anderson, Honnorez, et al., 1985; Becker, Sakai, et al., 1988). After five drilling campaigns at Hole 504B, a total depth of $1562.3 \mathrm{~m}$ below seafloor (mbsf), or $1287.8 \mathrm{~m}$ into basement, has been achieved (Fig. 2). Hole 504B is thus the deepest borehole yet drilled into the oceanic crust. In addition to drilling another $212.3 \mathrm{~m}$ into the massive units of Layer 2C, ODP Leg 111 provided the opportunity to conduct an extensive suite of in-situ experiments, including the recording of continuous electrical resistivity profiles over the entire length of the penetrated basement.

The extreme sensitivity of electrical properties to a large number of parameters makes electromagnetic methods both a complex and powerful technique with which to study large- and small-scale structures of rock formations. Although the electrical properties of rocks and minerals have been observed to vary over 24 orders of magnitude in the Earth (Olhoeft, 1981), the measurements made thus far in the oceanic crust have covered less than six orders of magnitude. In-situ measurements of electrical resistivity respond directly to conductivity changes in the rock surrounding the borehole. The presence of pores, cracks, and microcracks, either fluid-filled or plugged with precipitated conductive minerals such as chlorite and smectite, creates a path

\footnotetext{
${ }^{1}$ Becker, K., Sakai, H., et al., 1989. Proc. ODP, Sci. Results, 111: College Station, TX (Ocean Drilling Program).

2 Lamont-Doherty Geological Observatory, Palisades, NY 10964, and Department of Geological Sciences, Columbia University, NY 10964.
}

for current flow. The electrical conduction is a combination of electrolytic mechanisms for the pore spaces and the fluid-filled fractures and surface-mediated ion-transport mechanisms for conductive alteration minerals. Because an order of magnitude separates the resistivity of clays (a few ohm-m in situ) from that of seawater (about $0.2 \mathrm{ohm}-\mathrm{m}$ at $25^{\circ} \mathrm{C}$ ), the in-situ electrical resistivity of the basaltic basement reflects the progressive sealing of the oceanic crust with alteration products.

The resistivity of a saturated rock depends not only on pore space geometry, but also on the connectivity of the pores, the distribution of alteration products, and the connectivity of their active surfaces. As a consequence, the difficulty of precisely describing the topology of the pore space and the distribution of alteration products has led several authors to use empirical formulas such as Archie's law to relate resistivity and porosity. Such power laws have been used in widely differing cases, such as clastic sediments (Archie, 1942; Jackson et al., 1978; Lovell, 1985), basalt (Drury and Hyndman, 1979; Kirkpatrick, 1979; Rai and Manghnani, 1981; Becker, 1985; Broglia and Moos, 1988; Pezard et al., this volume), or even partly melted crustal rocks (Waff, 1974; Shankland and Waff, 1977; Hermance, 1979). A similar type of power law was derived in the laboratory from the study of pressurized samples for a large collection of rocks (Brace et al., 1965; Brace and Orange, 1968a, 1968b).

In order to study how the electrical resistivity of basalts is related to both porosity and alteration through possible surface conduction of clays (Drury and Hyndman, 1979; Olhoeft, 1981; Becker, 1985; Karato, 1985), a series of 32 basaltic cores from Hole 504B was analyzed in the laboratory. A companion paper in this volume (Pezard et al.) focuses on these measurements made on cores, tests the power law generally accepted as relating resistivity to porosity in basalt (Brace and Orange, 1968b; Drury and Hyndman, 1979; Becker, 1985), and tries to evaluate whether clays might play a significant role in the electrical resistivity measured during in-situ experiments. The purpose of this paper is to analyze the resistivity measurements obtained with a down- 


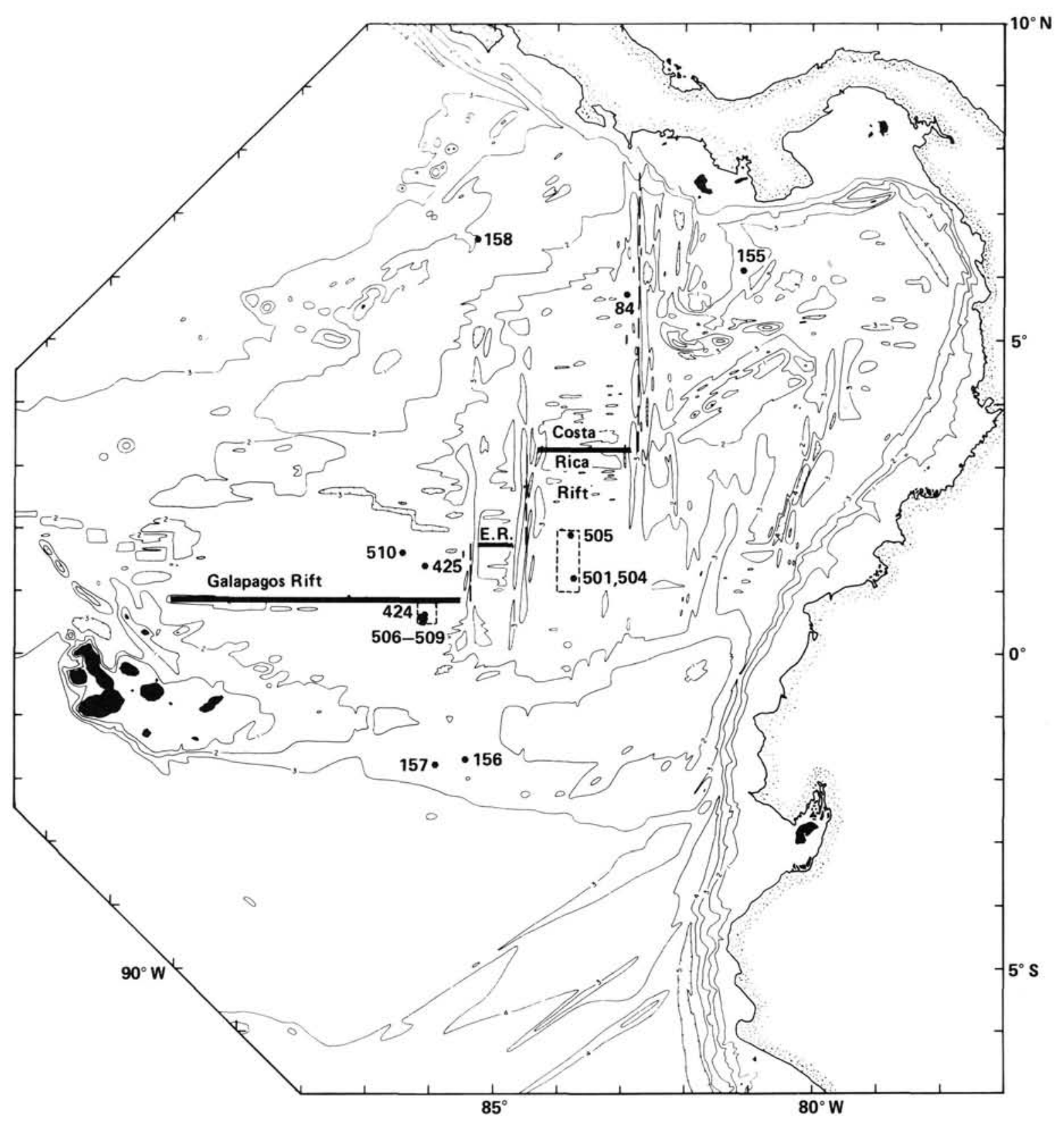

Figure 1. Location of Site 504 on the south flank of the Costa Rica Rift and other DSDP sites in the Panama Basin. Bathymetry from Lonsdale and Klitgord (1978). Contour interval $=1000 \mathrm{~m}$.

hole sensor and to compare them to those measured on cores in the laboratory. Taking into account the presence of conductive minerals resulting from the alteration of igneous phases through hydrothermal circulation, a porosity profile is derived from this analysis. The results obtained from this 5.9-m.y.-old crust are compared to previous measurements (Becker, 1985) and analyzed in the context of structural and alteration studies.

\section{IN-SITU ELECTRICAL EXPERIMENTS}

The Schlumberger dual laterolog (DLL) tool was run over the entire length of the basement in Hole 504B to measure with optimum vertical definition the "deep" and "shallow" electrical resistivities of the rock surrounding the borehole (Ellis, 1987; Shipboard Scientific Party, 1988). An estimate of total porosity and fracture porosity was computed aboard ship. In previous measurements, a Gearheart deep-resistivity laterolog was recorded down to $836 \mathrm{mbsf}$, but did not allow fracture porosity evaluation from its single scale of measurement (Cann and Von Herzen, 1983). During Leg 83, a large-scale resistivity experiment yielded excellent resistivity data from which a porosity profile for the basement was extracted (Becker, 1985).

A schematic of the DLL sonde run during Leg 111 is given in Figure 3, with an idealized sketch of the current flow within the rock. The principle of the DLL is to measure the intensity of a variable current focused in a 60 -cm-thick cylindrical beam, while flowing from a downhole electrode to a remote return under a fixed difference of potential (Serra, 1984; Ellis, 1987; Shipboard Scientific Party, 1988). The intensity of the measured current is inversely proportional to the formation resistivity. This sensor has the advantages of remaining accurate at high resistivity values (error less than $1.0 \%$ up to 40,000 ohm-m) and providing two measurements of resistivity (usually referred to as 


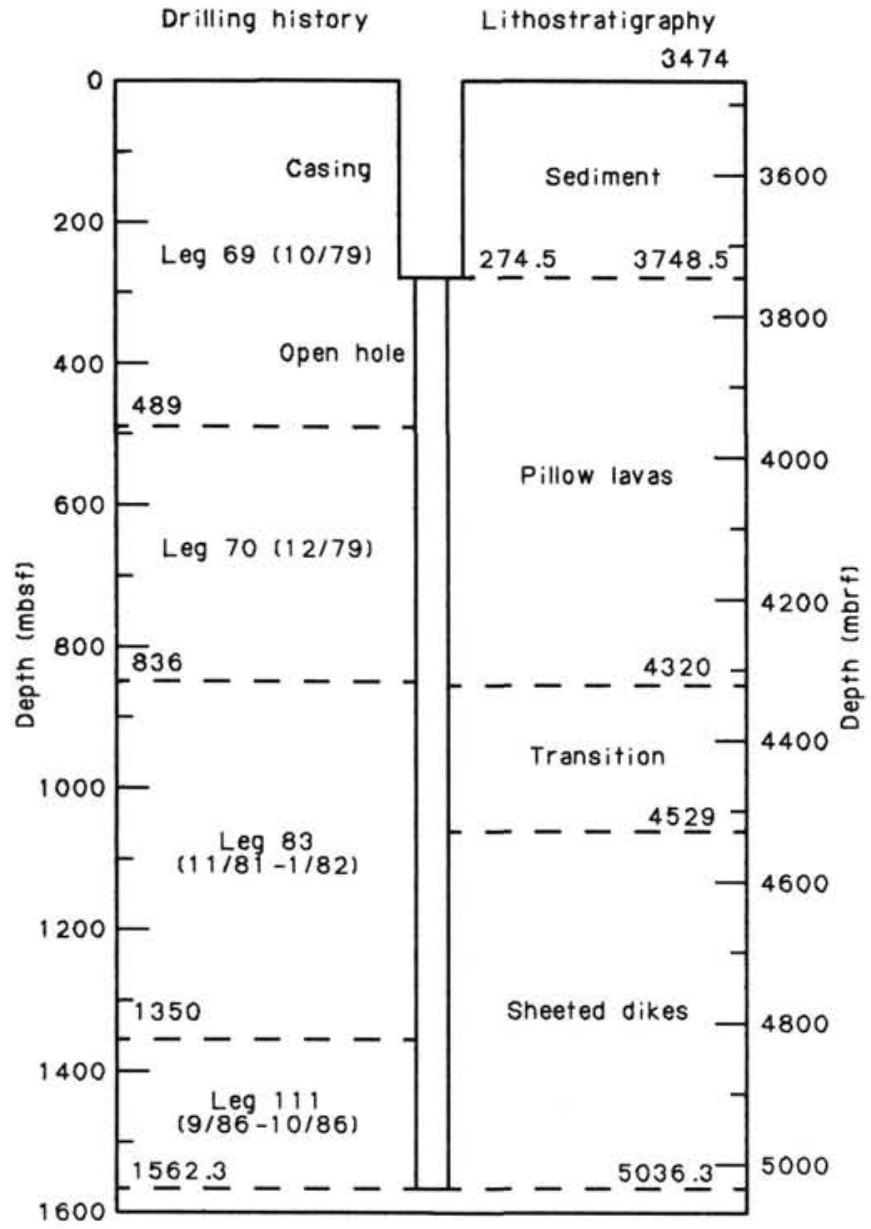

Figure 2. Schematic of Hole 504B drilling history and lithostratigraphy through the end of Leg 111.

"deep" and "shallow," in reference to their respective depth of horizontal penetration into the rock). On ODP Leg 111, the measurements made with the DLL covered depths from 5003 to $3758 \mathrm{~m}$ below rig floor (mbrf), or 1529 to $284 \mathrm{mbsf}$, with a datum acquired every $15 \mathrm{~cm}$. The resistivity values range from 3.0 ohm-m at the top of basement to about $1500.0 \mathrm{ohm}-\mathrm{m}$ at the bottom of the penetrated section (Fig. 5A). Besides having a different vertical resolution, these measurements are similar to those obtained by Becker (1985) with a long-spacing resistivity device. In both cases, an increase of about two orders of magnitude in resistivity values occurs across the interval from highly porous and altered Layers $2 \mathrm{~A}$ and $2 \mathrm{~B}$, where the average value in the pillows is about $10.0 \mathrm{ohm}-\mathrm{m}$, to the sheeted dikes of Layer $2 \mathrm{C}$, where the average value is about $250.0 \mathrm{ohm}-\mathrm{m}$ (Fig. $5 \mathrm{~A})$.

As a comparison, recent electromagnetic sounding of the seafloor has provided independent estimates of the bulk electrical conductivity of the upper part of the oceanic crust (Cox, 1971; Young and Cox, 1981; Cox et al., 1986), with a series of measurements conducted off-ridge axis on the East Pacific Rise. These measurements were best modeled with a $1.5-\mathrm{km}$-thick upper layer of high conductivity (about $0.1 \mathrm{~S} / \mathrm{m}$, which equates to $10.0 \mathrm{ohm}-\mathrm{m}$ ) and an underlying region with lower conductivity values $(0.04 \mathrm{~S} / \mathrm{m}$, or $250.0 \mathrm{ohm}-\mathrm{m})$, extending downward to about 6 or $7 \mathrm{~km}$. Whereas an excellent correspondence is found between electromagnetic sounding experiments and in-situ measurements in Hole 504B for the electrical resistivity, the evalua- tion of the thickness of the upper section (the extruded part of the volcanic edifice) has somewhat different results. This difference might be attributed either to an overestimate of the thickness of this upper layer from electromagnetic data (which is commonly the case in this type of modeling) or to variability of the large-scale structure of the oceanic crust (due to a different spreading rate controlling accretion in these two cases). In addition, the value of $250.0 \mathrm{ohm}-\mathrm{m}$ derived as an average to a depth of 6 to $7 \mathrm{~km}$ is reached at a depth as shallow as 1200 mbsf in Hole 504B. It is therefore reasonable to assume that such resistivity values would be obtained from future downhole experiments made in Hole 504B in the lower part of Layer 2 and in Layer 3. These low values of resistivity can be contrasted with measurements made with the same downhole sensor in granite at Cajon Pass, California, or in metamorphic rocks at Moodus, Connecticut (P. Pezard and R. N. Anderson, unpubl. data). In these two cases, values beyond $100,000 \mathrm{ohm}-\mathrm{m}$ were commonly measured. This large difference tends to suggest that the oceanic crust might be (or might have been) quite permeable and that fluids might have permeated well within Layer 3 during the initial cooling phase.

\section{DATA ANALYSIS}

An estimate of total and fracture porosity was computed aboard ship from the DLL resistivity data. The relationship between porosity and resistivity for basaltic rocks was discussed at length by Becker (1985), who concluded, after Brace and Orange (1968a), Drury and Hyndman (1979), Karato (1985), and others, that the use of Archie's formula with $a=1.0$ and $m=$ 2.0 was a reasonable compromise to relate resistivity to porosity in basaltic rocks. However, the use of Archie's formula in basaltic rocks has not yet been rigorously justified, and a single relationship, with $a$ and $m$ considered as constants, cannot realistically be thought to hold throughout the entire length of the hole (Becker, 1985). In spite of these limitations, we used the same reasoning to obtain a first-order porosity estimate from the resistivity data. The deep resistivity of the rock corrected for borehole effect $\left(L L d_{c}\right)$ was used to compute this first estimate of porosity $(\phi)$ with

$$
\phi^{2}=\left(R_{w} / L L d_{c}\right)
$$

where $R_{w}$ is the resistivity of the pore fluid, considered identical to that of seawater (Mottl et al., 1983) and corrected for the effect of temperature (Becker, 1985).

Similarly, a semiempirical method based on DLL data was used to estimate the fracture porosity of the basaltic basement. This method was initially developed to study fractured-carbonate hydrocarbon reservoirs (Boyeldieu and Winchester, 1982; Boyeldieu and Martin, 1984; Sibbit and Faivre, 1985) and is based on the comparison of deep and shallow laterolog measurements. For this, the DLL is considered as a deep-penetrating sensor of the fracture pore space $\left(\phi_{F}\right)$, and the estimate of fracture porosity is computed assuming that rock and fracture resistivities are measured in parallel by the DLL (Fig. 4). Because of the electrode arrangement, the deep measurement $(L L d)$ is representative of mostly the horizontal resistivity of the rock formation (Serra, 1984), and hence is hardly affected by the presence of vertical conductive events such as fractures. The shallow measurement $(L L s)$ is sensitive to both horizontal and vertical resistivity of the rock and is consequently reduced by the occurrence of both types of fractures. Thus, the presence of horizontal conductive fractures decreases the deep measurement more than the shallow one. As the estimate of fracture porosity $\left(\phi_{F}\right)$ is related to the difference between $L L d$ and $L L s$, it might be considered as a minimum value because the presence of both types of networks might have conflicting effects. 

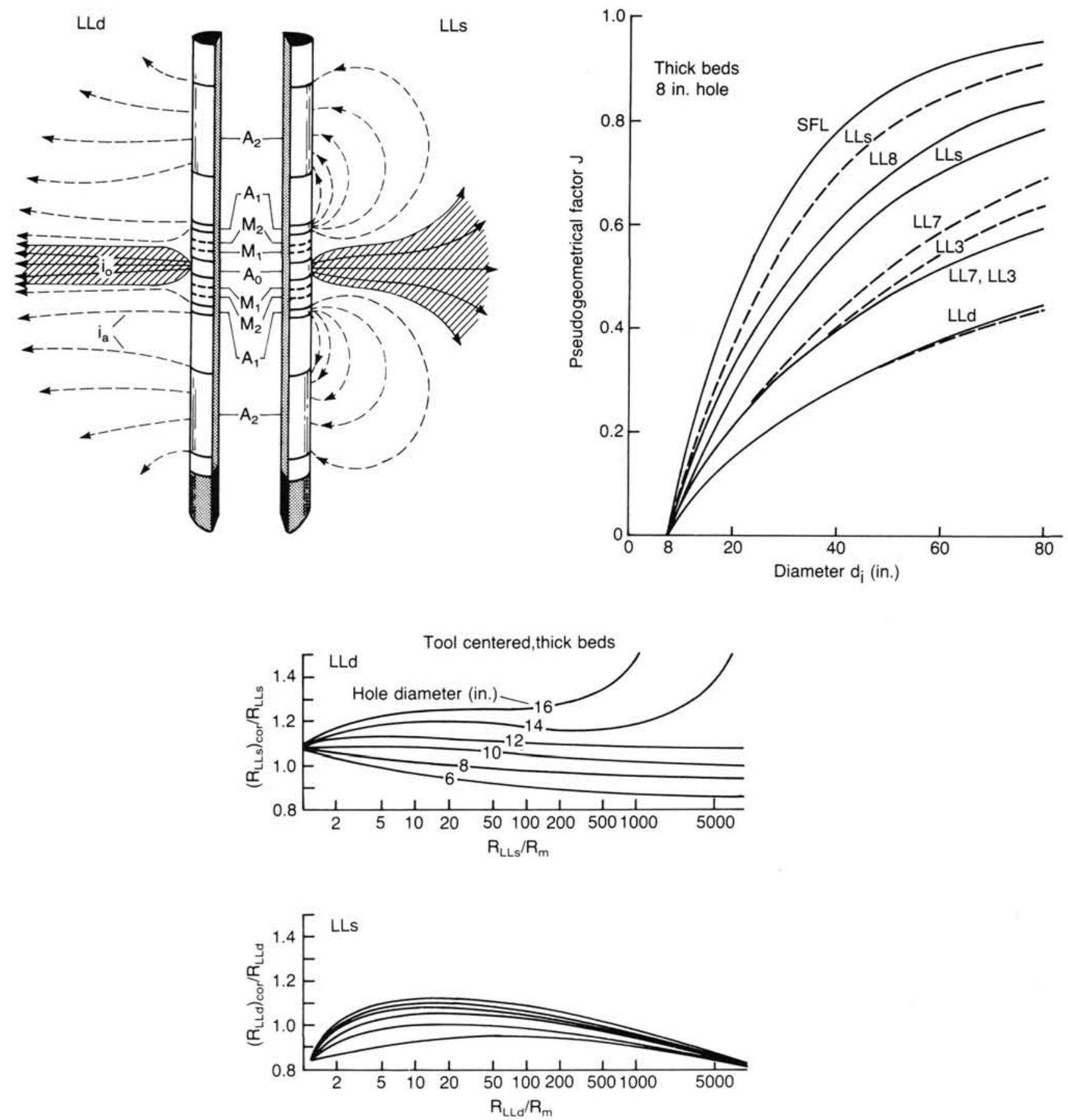

Figure 3. Sketch of the dual laterolog sonde (DLL) and idealized current flow into the rock, with the "shallow" current ( $L L S)$ to the right and the "deep" current $(L L d)$ to the left. The electrode arrangement is labeled in the middle of the split sonde.

When the porosity structure of a hydrocarbon reservoir is being analyzed, a large resistivity contrast is present between waters located in and around the borehole (usually saline and conductive) and hydrocarbons located in the reservoir. In the case of the upper oceanic crust drilled with seawater, borehole and pore fluids have similar salinities (Mottl et al., 1983), and the invasion of the fractures by a fluid of a different salinity than that of seawater can be ignored. The difference between $L L s_{c}$ and $L L d_{c}$ is then attributed solely to an anisotropic distribution of the pore space in the rock. In addition, the fact that drilling-related fractures do not extend more than a few decimeters away from the borehole (Kirsch, 1898), far less than the rock volume investigated with the DLL, suggests that they contribute little to the overall signal.

The sketch of two extreme types of fractured rocks in Figure 4 shows that subhorizontal conductive fractures are seen in parallel with the basaltic matrix for the deep measurement, which consequently reduces the value of $L L d$ more than that of $L L s$ 
A


B

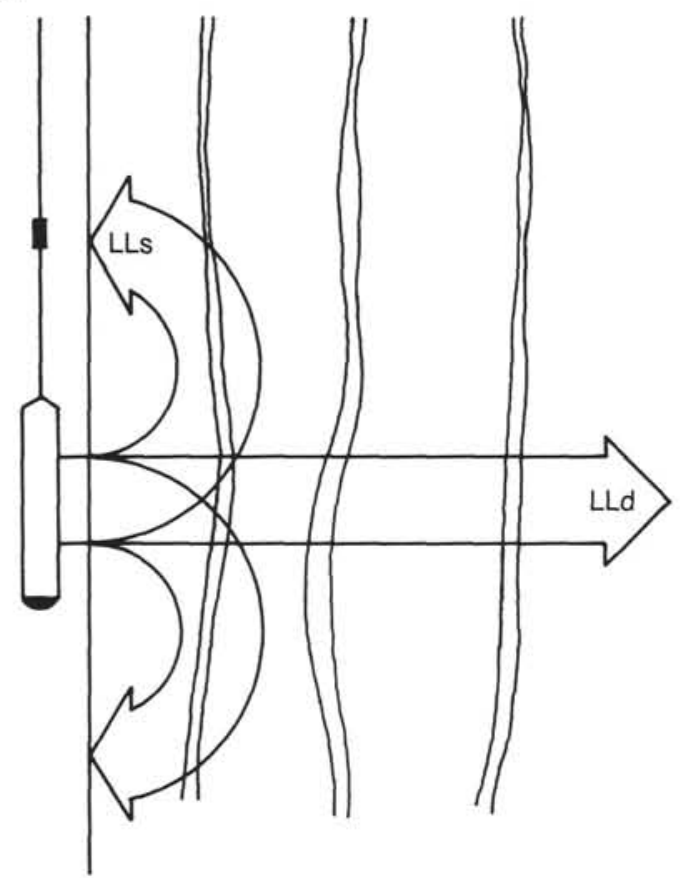

C

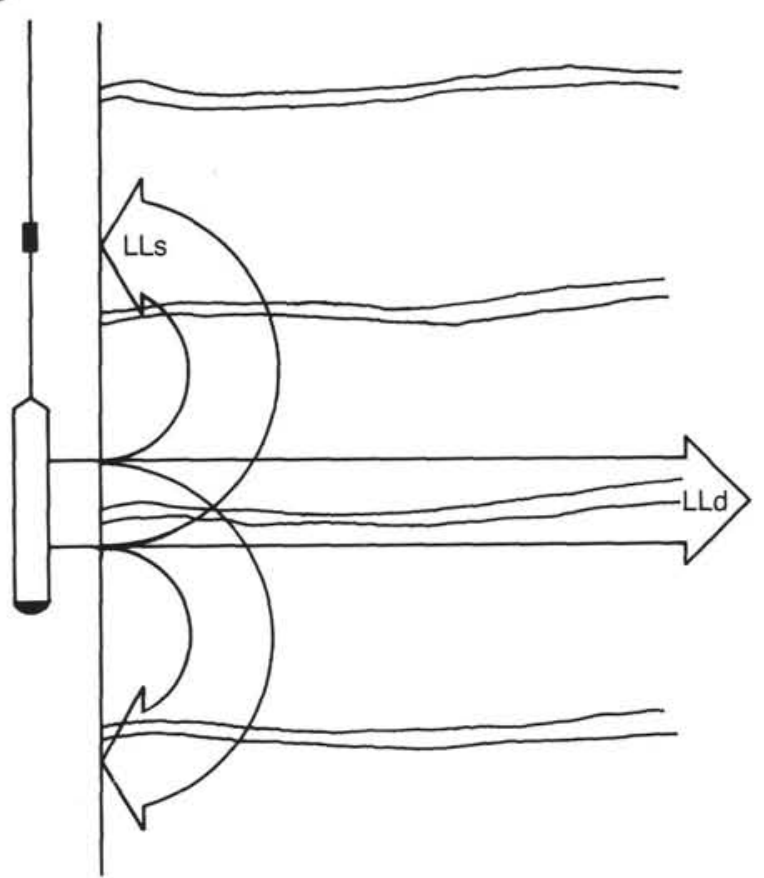

Figure 4. A. Resistivity model for matrix and fractures seen by the laterolog measuring currents, with an analogy to electrical circuits in parallel. $\mathrm{C}=$ conductivity; $\mathrm{Rma}=$ matrix resistivity; $\mathrm{Rfr}=$ fracture resistivity. $\mathbf{B}$. Idealized vertical fracture network. $\mathbf{C}$. Idealized horizontal fracture network.

$(L L d<L L s)$. In the case of a subvertical network, the relationship is reversed $(L L s<L L d)$, and the equation derived by Boyeldieu and Winchester (1982) can be rewritten as

$$
\begin{aligned}
\text { VFRPHI }>\text { VFRPHI(min) }= & \left(\left[1 / L L s_{c}-1 / L L d_{c}\right] /\right. \\
& {\left.\left[1 / R_{w}\right]\right)^{1 / m f}, }
\end{aligned}
$$

where VFRPHI is the "subvertical" fracture porosity, VFRPHI(min) the estimate for vertical fracture porosity, and $m f$ the exponent in Archie's formula for the fracture network. As an estimate of fracture porosity, this computation defines only a lower limit because the presence of any horizontal fractures decreases $L L d_{c}$ significantly, which consequently tends to reduce the estimate for vertical fracture porosity VFRPHI(min). Similarly, a subhorizontal distribution of fractures would give

$$
\begin{aligned}
\text { HFRPHI }>\text { HFRPHI(min) }= & \left(\left[1 / L L d_{c}-1 / L L s_{c}\right] /\right. \\
& {\left.\left[1 / R_{w}\right]\right)^{1 / m f}, }
\end{aligned}
$$

where HFRPHI is the "subhorizontal" fracture porosity and HFRPHI(min) the estimate for horizontal fracture porosity. These two estimates of fracture porosity are plotted in Figure $5 \mathrm{~B}$. The remaining area between fracture porosity (computed as VFRPHI(min) + HFRPHI(min); Fig. 5B) and total porosity $(\phi)$ is therefore a measurement of residual porosity. This residual is supposed to equate to intergranular pore space, as no vesicular pore space was observed in the cores for these tholeiitic submarine basalts.

One of the main shortcomings related to the use of constant parameters for Archie's formula over the entire length of the drill hole (here $a=1.0$ and $m=2.0$ ), however, is that the variations of rock type, pore space distribution, or alteration facies are not accounted for. Particularly, the presence of conductive clay minerals, such as smectites and chlorites, should be considered in order to avoid misinterpreting them as pore space. In order to account for this, the surface conduction associated with the presence of clays was first mentioned as playing an important role in decreasing the electrical resistivity of sedimentary 


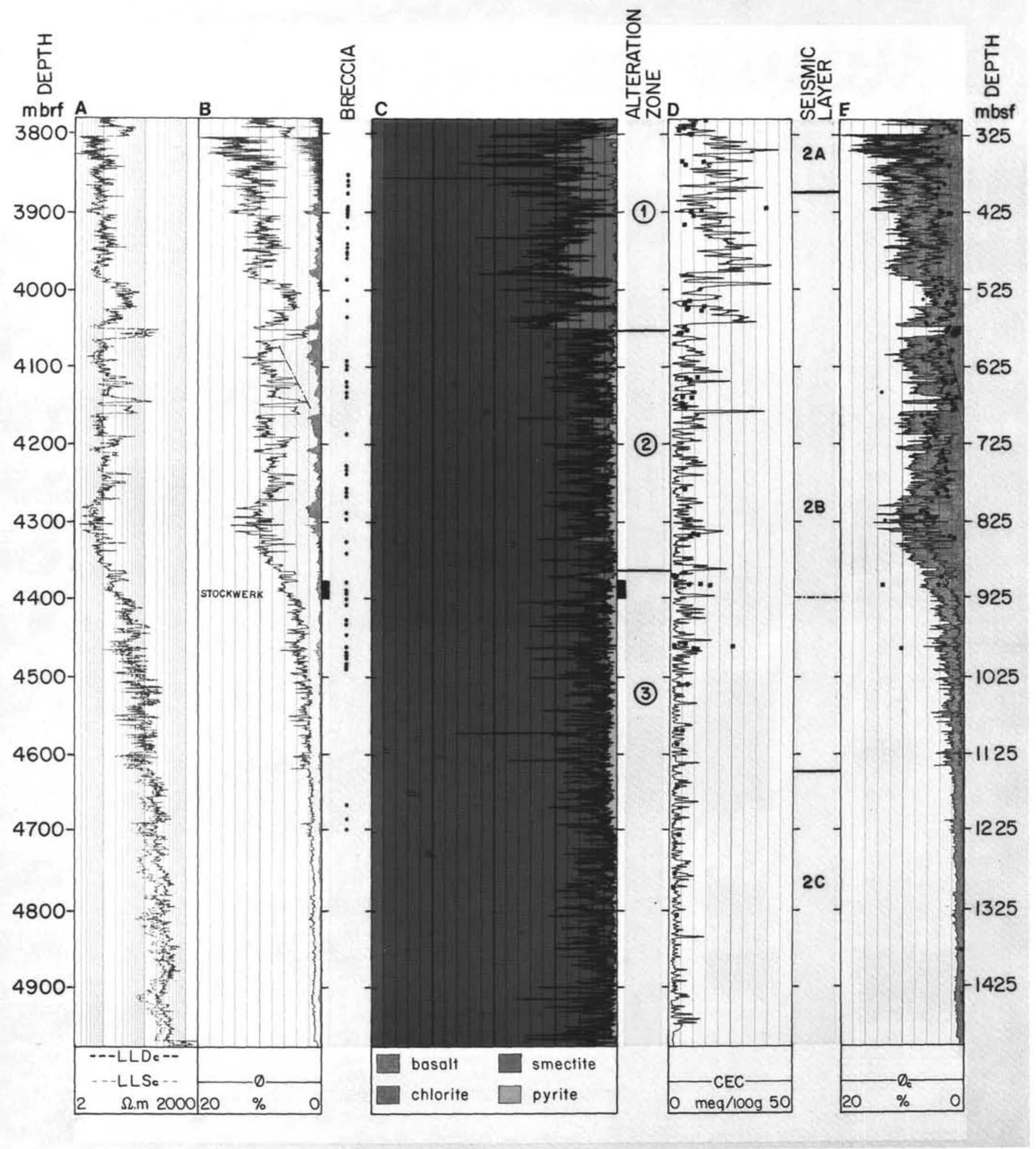

Figure 5. A. Resistivity data recorded in Hole 504B during Leg 111 (Shipboard Scientific Party, 1988). B. Total porosity and fracture porosity (blue), derived from Archie's formula (Becker, 1985; Shipboard Scientific Party, 1988). C. Simplified mineralogy derived from the analysis of the geochemical log data (Anderson et al., this volume). D. CEC profile estimated from the geochemical log data; the solid dots are the CEC measurements made on cores (Pezard et al., this volume). E. Clay-corrected porosity profile (green) compared to Archie-derived profile (purple); the solid dots are the porosity measurements made on cores (Karato, 1985; Christensen and Salisbury, 1985; N. I. Christensen, pers. comm., 1988; Pezard et al., this volume). The locations of breccias observed in cores (from Shipboard Scientific Party, 1988), alteration boundaries (from Alt et al., 1985), and large-scale seismic layers (from Anderson et al., 1985b) are plotted for reference. 
rocks by Winsauer and McCardell (1953), and then Hill and Milburn (1956), and associated to an electrical circuit located in parallel to the pore space (Waxman and Smits, 1968) with

$$
\mathrm{FF}^{\prime \prime}=\left(C_{w}+B Q_{v}\right) / C L L d_{c},
$$

where

$$
\begin{aligned}
\mathrm{FF}^{\prime \prime}= & \text { formation factor of the rock corrected for clay } \\
& \text { conductivity, } \\
C_{w}= & \text { conductivity of the pore fluid, } \\
B= & \text { equivalent conductance of the sodium ions ab- } \\
& \text { sorbed onto the clays, } \\
Q_{v}= & \begin{array}{l}
\text { cation exchange capacity of the rock normalized } \\
\\
\text { to unit pore volume, }
\end{array} \\
C L L d_{c}= & \text { conductivity of the fluid-bearing rock measured } \\
& \text { by the deep laterolog. }
\end{aligned}
$$

Rink and Schopper (1974) and Clavier et al. (1977) developed more sophisticated models (reviewed in Pape and Worthington, 1983; Serra, 1984; Ellis, 1987). These models refer as well to the analogy of resistors in parallel used by Waxman and Smits (1968) to describe the conductance of clay-bearing rocks. In order to account for the presence of clays, these authors emphasize the need to determine the intrinsic formation factor of each analyzed core sample, with measurements made using different fluid salinities, rather than the apparent formation factor $(F F)$ obtained from one point only (see, in particular, Worthington, 1985). Here again, the behavior of the rock-clay-fluid assemblage at low-fluid conductivity depends considerably on the pore space distribution. For example, Clavier et al. (1977) showed that the apparent formation factor decreases to values near zero at low resistivity for shaly sands, whereas Pape et al. (1985) found that it rises to infinity in slightly altered granites (in fact, $1 / F F$ goes to zero). In both cases, they concluded that conduction at low fluid salinity is primarily due to the interlayer conductivity of the clays. Such opposite behavior stresses the need to consider each assembly age individually in order to be able to study the appropriate small-scale conduction mechanism.

In the case of basaltic rocks, the influence of clay conductivity on resistivity was studied and discussed by Drury and Hyndman (1979), Olhoeft (1981), and Karato (1985). In particular, Olhoeft (1981) showed that surface conduction of clays, usually negligible at low temperature, becomes as important as pore conduction at about $80^{\circ} \mathrm{C}$ and predominant at higher temperatures. This temperature dependence might then play an important role in controlling the resistivity of in-situ measurements in deep, hot boreholes such as Hole 504B. The derivation of a more accurate resistivity-porosity transform seems therefore related first to a precise estimation of the conducting clay fraction and second to the study of the temperature dependence of conduction on clay surfaces.

The cation exchange capacity (CEC) is used to characterize the ability of a clay-rich rock sample to absorb electrolytic cations onto pore surfaces, hence creating an additional path for current conduction in parallel to the pore space. The CEC of a rock sample is related to the mobility of the cations (which is equivalent to the adsorption capacity of the clay mineral for a given type of cation), the charge density per unit area, and the specific surface area of the clays distributed on pore surfaces. However, the CEC of rocks cannot be directly and continuously measured at present in a borehole. Measurements of CEC are therefore limited to either in-situ complex resistivity experiments or chemical analysis in the laboratory. Such difficulty has consequently required the reconstruction of synthetic CEC profiles from other continuous measurements, on the basis of the calibration points obtained in the laboratory. In particular, the re- cent development of geochemical logging has provided a way to extract petrophysical parameters such as the CEC from the derived mineralogy (Herron, 1986). Assuming that the relative proportions of each clay mineral of known CEC is provided from the mineralogy derived from the geochemical log, an estimate of the CEC of the rock assemblage can be computed using a linear summation.

The mineralogical inversion of the geochemical data recorded in Hole 504B during Leg 111 is discussed in detail by Anderson et al. (this volume), and the results are presented in Figure 5C. The elemental composition was solved for the presence of smectite $(50 \mathrm{meq} / 100 \mathrm{~g})$ and chlorite $(10 \mathrm{meq} / 100 \mathrm{~g})$ and then used as input to obtain the reconstructed CEC curve (Fig. 5D). In addition, a total of 61 samples selected from Hole 504B was analyzed in the laboratory and measured for CEC (Pezard et al., this volume). In the cores, the quasiuniform presence of smectites as an alteration phase of olivine is reflected by high values of CEC in the extrusive part of the crust (Fig. 6). In the massive flows of Layers $2 \mathrm{~A}$ and $2 \mathrm{~B}$, the average $\mathrm{CEC}$ is high $(5.8 \mathrm{meq} /$ $100 \mathrm{~g}$ ). Because low initial porosity constrains a low permeability and, in turn, a low water/rock ratio during hydrothermal circulation, a small amount of alteration might be expected from the low average porosity $(1.4 \%)$ and the absence of fractures in most of these samples selected from massive units. To the contrary, the more porous and fractured pillows have an average $C E C$ value of $10.2 \mathrm{meq} / 100 \mathrm{~g}$ (Pezard et al., this volume). In the massive units of Layer $2 \mathrm{C}$ where greenschist facies of alteration are observed, the average CEC value decreases to $2.3 \mathrm{meq} /$ $100 \mathrm{~g}$. The CEC laboratory measurements and the reconstructed CEC profile plotted for comparison in Figure 5D are in excellent agreement throughout the hole, although more measurements in the extremely altered upper part of the basement would be desirable.

A new estimate of porosity $\left(\phi_{c}\right)$ was consequently computed from the equation of Waxman and Smits (1968) and the conservative approach followed by Becker (1985), in which $a$ and $m$ are set to 1.0 and 2.0 , respectively:

$$
\phi_{c}^{2}=C L L d_{c} /\left(C_{w}+B Q_{v}\right),
$$

where $B$ reflects the sodium charge mobility and is estimated from Serra (1984) as

$$
B=4.6\left(1.0-0.6 e-0.077 / R_{w}\right),
$$

and $Q_{v}$ is the CEC normalized to unit pore volume, obtained from

$$
Q_{v}=\operatorname{CEC}\left({ }^{\circ}\right)([1-\phi] / \phi),
$$

with $\left({ }^{\circ}\right)$ representing the bulk density of the material.

As porosity $\left(\phi_{c}\right)$ is the estimated parameter, an initial guess for porosity $(\phi)$ was necessary as an input to the previous equation in order to start to iterate toward a solution constrained by core measurements. The initial value of porosity $(\phi)$ obtained from Archie's formula was subsequently used to normalize $Q_{v}$ and, therefore, estimate $\phi_{c}$. Whereas the estimate of porosity $(\phi)$ derived from Archie's formula proposes relatively high values of total porosity (Fig. $5 \mathrm{E}$ ), the clay-corrected estimate $\left(\phi_{c}\right)$ obtained after the first iteration reduces the previous estimate by half in Layers $2 \mathrm{~A}$ and $2 \mathrm{~B}$ and to almost zero in the transition zone and the dikes of Layer $2 \mathrm{C}$. This first clay-corrected estimate (shaded green Fig. 5E) appears to be in good agreement with the core measurements throughout the hole. Such an agreement would be expected if the samples analyzed in the laboratory were fully representative of in-situ physical properties. Unfortunately, large-scale features such as cracks and voids, for ex- 
ample, are notoriously not sampled in the coring process and consequently not analyzed in the laboratory. In any case, the laboratory measurements should be considered as a lower limit of porosity estimates derived from in-situ measurements.

Within Layer 2C, the good agreement between the core measurements and the model at porosity values of the order of $0.1 \%$ is compatible with the low values of permeability measured in situ (Anderson et al., 1985b; Becker, 1985, this volume). At the base of Layer 2B (600 to $850 \mathrm{mbsf}$ ), however, the agreement at values around $3.0 \%$ becomes questionable, as similar low values of permeability were obtained in situ. An explanation for this apparent contradiction might arise if the porosity measured in the laboratory equates to water molecules adsorbed onto clay surfaces (referred to as "bound water"). Such water would be measured as porosity when the samples are heated in the laboratory, but would offer shear resistance to free-water flow in the pore space during in-situ permeability experiments. The fit of the model to laboratory measurements would in this case be fortuitous, and this clay-corrected porosity profile should hence be considered only as a first-order approximation (knowing that $a$ and $m$ were chosen arbitrarily). A more precise evaluation must await an adequate correction of the neutron porosity log for the massive basaltic units, from which insitu values for $a$ and $m$ can be determined (Broglia and Ellis, 1988).

\section{DISCUSSION}

\section{Alteration and Morphology of the Upper Oceanic Crust}

The boundaries between the three major regions of alteration obtained from the analysis of thin sections in Hole 504B (Alt and Emmermann, 1985; Emmermann, 1985; Alt et al., 1985,1986 ) are shown in Figure 5. The upper alteration zone (1) is characterized by reactions of basalt with seawater occurring at low temperature (below $60^{\circ} \mathrm{C}$ ) and by the presence of iron hydroxides, celadonite-nontronite, or saponite as a replacement for olivine throughout the rock. The middle section (2) is characterized by reactions at higher temperatures $\left(60^{\circ}\right.$ to $\left.110^{\circ} \mathrm{C}\right)$, with evolved fluids possibly reacted already within the crust, and the presence of dominantly pyrite and saponite as alteration products. This boundary is abruptly outlined by the geochemical log data (Fig. 5C), and the strong mineralogical zonation indicates the presence of a permeability barrier between these two alteration zones. This permeability barrier is shown on the corrected porosity profile (Fig. $5 \mathrm{E}$ ) by a 15 -m-thick low-porosity $(0.5 \%$ on average) section that equates to lithostratigraphic Unit 27 , described from the cores as a moderately phyric massive flow (Cann, Langseth, et al., 1983). This morphological feature therefore constitutes the boundary between two distinct hydrological regimes in the immediate vicinity of the drill hole. In a similar way, the transition from suboxic alteration facies (alteration zone 2; Fig. 5) to greenschist facies (zone 3) is at $4372 \mathrm{mbrf}$ (898 mbsf; Alt and Emmermann, 1985; Emmermann, 1985) or 4364 mbrf ( 889 mbsf; A. Adamson, pers. comm., 1988), where a pair of low-porosity units of intrusive origin are located (probably Units 57 and 61). Thus, a strong lithologic control of the alteration distribution is observed in this hole.

Whereas certain massive units appear to constitute permeability barriers (such as Unit 2D; Shipboard Scientific Party, 1988 ) or alteration boundaries (Unit 27) in the extrusive part of the crust, they surprisingly appear rather altered throughout their groundmass. This alteration was observed both directly in thin sections or from CEC measurements made on cores (Fig. 6; Pezard et al., this volume). These thick, poorly porous units might consequently be viewed as "valves" in the hydrothermal system of young oceanic crust. These valves remain closed during most of the life of the plate, but might open themselves to pervasive alteration via fluid circulation during dilatancy events or the initial cooling of the crust. It is equally interesting to notice that the three major peaks of alteration reflecting intense smectite precipitation found at 4165,4330 , and $4380 \mathrm{mbrf}(690$, 855 , and 905 mbsf, respectively; Fig. 5C), are each located below a massive unit (Units 34,53 , and 61 , respectively). The latter two massive units, described as intrusive units (Adamson, 1985), might as well be related to the stockworklike section (Anderson, Honnorez, et al., 1985) only a few meters underneath the base of Unit 61 (4380-4400 mbrf, or 905-925 mbsf; Fig. 5). This indicates again a strong relationship between small-scale crustal morphology, structure, and hydrothermal circulation patterns.

While alteration appears uniform and widespread in the extrusive part of the crust (i.e., down to $4365 \mathrm{mbrf}$, or $890 \mathrm{mbsf}$ ), with high and uniform values of CEC measured on cores (Pezard et al., this volume), the transition zone (4375-4610 mbrf, or $900-1135 \mathrm{mbsf}$ ) provides large and rapid variations with depth of CEC measurements. Such rapid variations suggest an extreme segmentation of the crust in this transition zone and the underlying dikes of Layer 2C, as proposed by Alt et al. (1985). These conditions were also observed in the Semail ophiolite complex of Oman (T. Juteau; pers. comm., 1988). Besides the extreme segmentation of the crust in the lower part of the drill hole, the extremely low CEC values recorded on four samples (selected from Units 59, 63, and 74) point to units intruded within a different alteration environment than the host rock.

\section{Large-Scale Layers of the Oceanic Crust}

\section{Layer $2 A$}

The distribution of fracture porosity in the first few hundred meters of basement (Figs. 5B and 6) changes at 3880 mbrf (406 mbsf) from an overlying zone of both horizontal and vertical networks to a regime of mainly vertical fractures beneath. This boundary is also the site of a decrease in total porosity (Figs. 5B and 6), which fits with previous definitions of the limit between Layers 2A and 2B in Hole 504B (CRRUST, 1982; Anderson et al., 1985a; Newmark et al., 1985) and the original concept of a fractured, low-velocity Layer 2A (Houtz and Ewing, 1976; Francheteau, 1983). The upper 130-m section of the basaltic basement has the highest porosities of the entire hole, with an average of $7.0 \%$ in the pillows, and appears as the most intensively altered interval both in the thin sections and from the analysis of geochemical log data (Anderson et al., this volume; Fig. 5C). The section of most intense fracturing observed within Layer $2 \mathrm{~A}$ is bounded on top by a 14-m-thick massive flow (Unit 2D; from 3785 to $3799 \mathrm{mbrf}$, or 311 to $325 \mathrm{mbsf}$ ), to which it might be genetically related.

The set of temperature profiles recorded during successive scientific legs in Hole 504B (Fig. 7A; Gable et al., this volume) shows that the bottom of Unit 2D precisely defines the depth at which the temperature starts to increase rapidly as the ocean water enters the underpressured aquifer (Anderson and Zoback, 1982; Anderson et al., 1985b), which is the upper limit of the zone of water intake into the crust. The temperature gradient recorded during Leg 111 (Fig. 7B) indicates that the interval of water inflow is $30 \mathrm{~m}$ thick, which equates to the section of highest porosity exactly below Unit $2 \mathrm{D}$ (Figs. 5B and 5E). This relationship has several possible implications. First, it suggests that the structure allowing the underpressured aquifer to develop was created at the ridge axis, where Unit 2D was emplaced. Second, an underpressured zone possibly appeared in this high-permeability conduit during sealing of the upper part of the crust related to the diagenesis of diatom oozes into chert, about $1 \mathrm{~m} . \mathrm{y}$. ago (Hobart et al., 1985). Third, it means that hydrothermal waters already circulated once through the crust might be trapped 

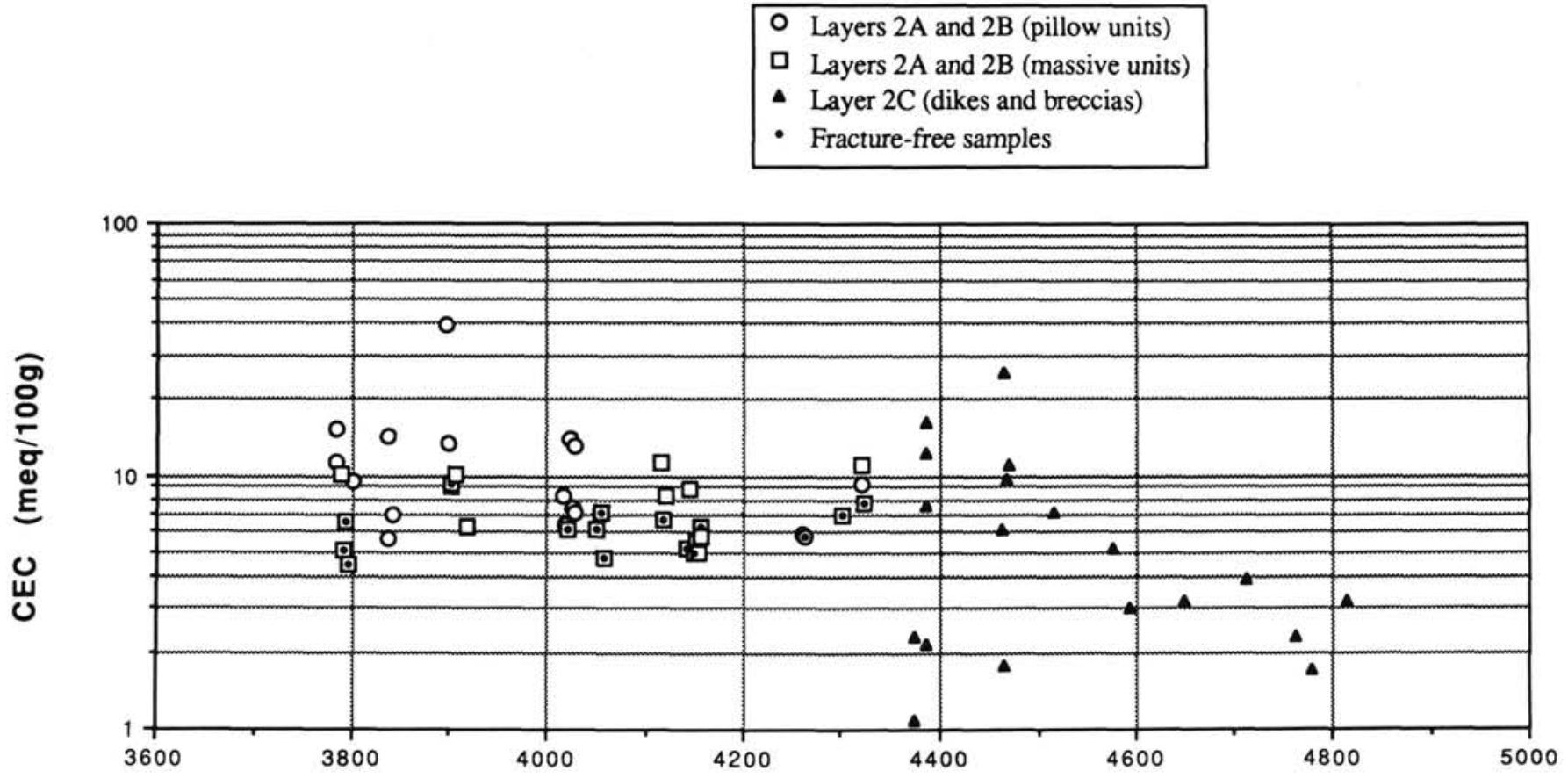

Depth (mbrf)

Figure 6. Laboratory measurements of CEC plotted as a function of depth. The decrease in the amount of smectite (mostly saponites) from the upper part of the basement (Layers 2A and 2B) to the sheeted dikes of Layer 2C (characterized by greenschist facies of alteration) is reflected in a discernible decrease of the CEC within Layer $2 \mathrm{C}$. The fracture-free samples of Layers $2 \mathrm{~A}$ and $2 \mathrm{~B}$ commonly have the lowest CEC values in the extrusive part of the crust.

at shallow depth below such thick units close to the ridge axis. These waters may then cool and circulate laterally through to the large horizontal fracture porosity before being eventually recycled into the crust (Alt et al., 1985). Specific types of alteration minerals should be expected from the reaction of basement rocks with such evolved water, already reacted once at high temperatures. This process could consequently explain the second stage of alteration described for the dikes of Hole 504B (Alt et al., 1985), with formation of quartz, epidote, and sulfides from more evolved (Mg-depleted and metal-, $\mathrm{Si}$-, and ${ }^{18} \mathrm{O}$-enriched) fluids.

Similar borehole in-flows have been encountered in other deep-sea drill holes, although never studied as extensively as Hole 504B. A kilometer away from Hole 504B, DSDP Hole 501 penetrated $73 \mathrm{~m}$ into basement. Two massive flows, comparable in size to Unit 2D in Hole 504B, were drilled through halfway into the hole (Fig. 7C). Here again, in-situ temperature measurements indicated the presence of a downward water flow in a zone below a massive unit (Becker et al., 1983; Fig. 7C). DSDP Hole 395A, located in the North Atlantic, provides an excellent point of comparison with Hole 504B, with probably the most puzzling example of the relationship between aquifers and massive units. The drill hole penetrated $93 \mathrm{~m}$ of sediments and 571 m of basaltic basement (Melson, Rabinowitz, et al., 1979; Fig. 8 ). The sequence of increasing electrical resistivity (or decreasing porosity) with depth was interpreted as magma cycles (Hyndman and Salisbury, 1984; Fig. 8), with each sequence proposed to represent a single eruptive cycle. These cycles start at the bottom with high electrical resistivity, low-porosity massive flows and then gradually evolve to low electrical resistivity, high-porosity breccias toward the top, representing the last phase of the eruptive sequence. Each of these sequences is truncated at its top by an abrupt change in physical properties corresponding to the onset of the next volcanic cycle. These decreasing porosity trends are emphasized by a dashed line on the resistivity record (Fig. 8), and each section with resistivity values in excess of 30 ohm-m at the base of these sequences is indicated on the temperature record. The downward flow of seawater, as indicated on the successive temperature logs recorded during DSDP Leg $78 \mathrm{~B}$, appears to enter the basement below the base of the previously defined massive units ( $3 \mathrm{~A}$ and $4 \mathrm{~A}$, Fig. 8). The temperature $\log$ recently recorded during ODP Leg 109 provides evidence for seawater flow into Unit 5A (Fig. 8; Detrick, Honnorez, et al., 1988). These successive observations indicate the presence of several underpressured aquifers located at different depths in Hole 395A, as opposed to the single in-flow zone found at present in Hole 504B. Such a structural and hydrologic contrast emphasizes the differences in morphology of the basaltic basement between two plates accreted at different spreading rates.

\section{Layer $2 B$}

Analysis of the resistivity data has outlined the presence of dominantly vertical fractures from the top of Layer 2B (3880 mbrf, or $405 \mathrm{mbsf}$ ) to the bottom of the hole (Shipboard Scientific Party, 1988). The low values of clay-corrected porosity in the massive units (less than $2.0 \%$ ) provide a means to discriminate the flows and sills from the more porous pillow units (Fig. $5 \mathrm{E})$. The fracturing in the penetrated flows is mainly restricted to the cooling edges $(4055,4158$, and 4200 mbrf; Shipboard Scientific Party, 1988), whereas the intensity of fracturing within pillow units is observed as being of two possible origins: (1) thermal, due to stresses applied during cooling of a contiguous massive unit $(4045,4065$, and 4160 mbrf; Fig. 5B), or (2) tectonic, due to basement faulting (3970 and $4280 \mathrm{mbrf}$ ). 


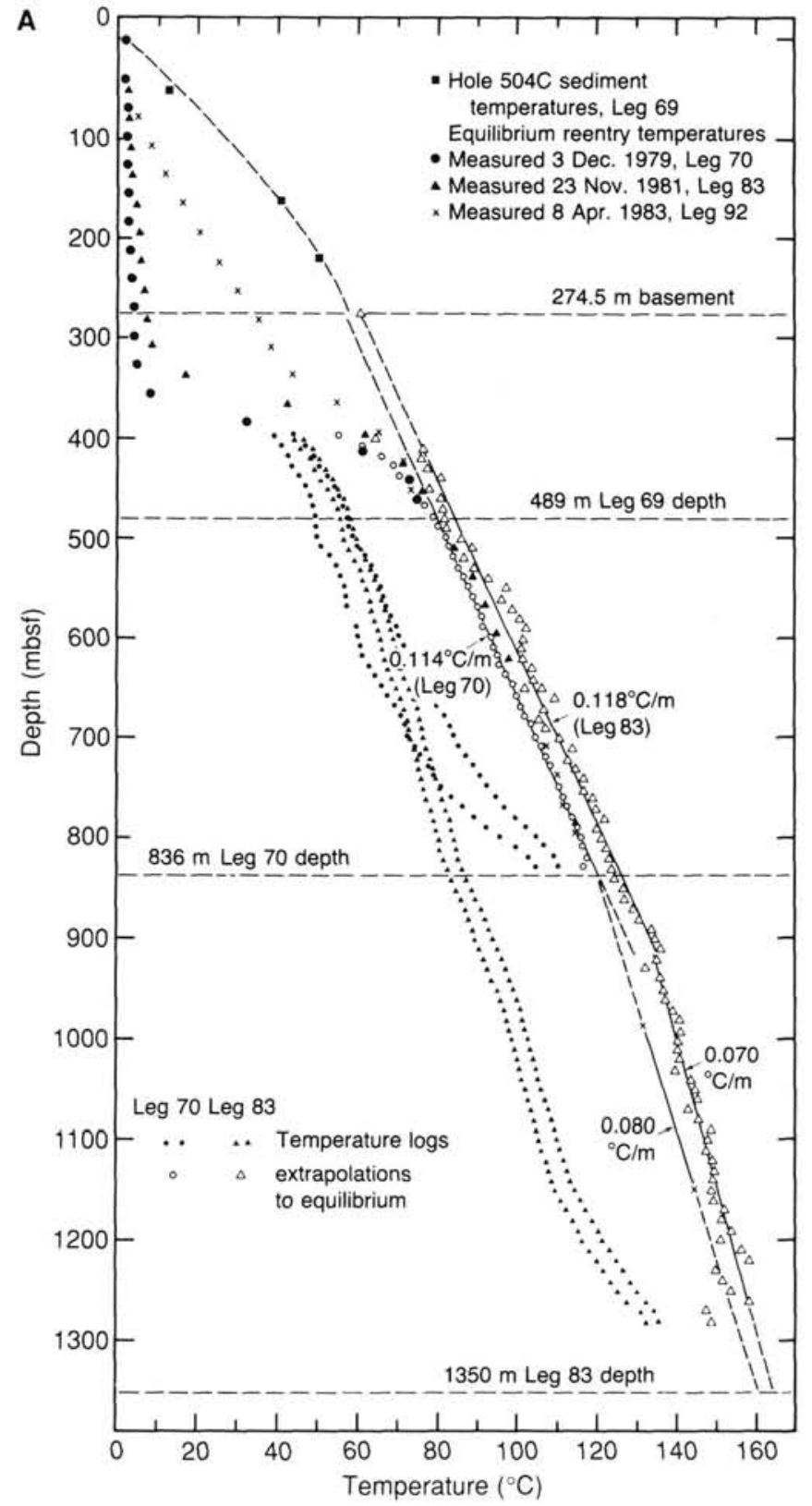

B

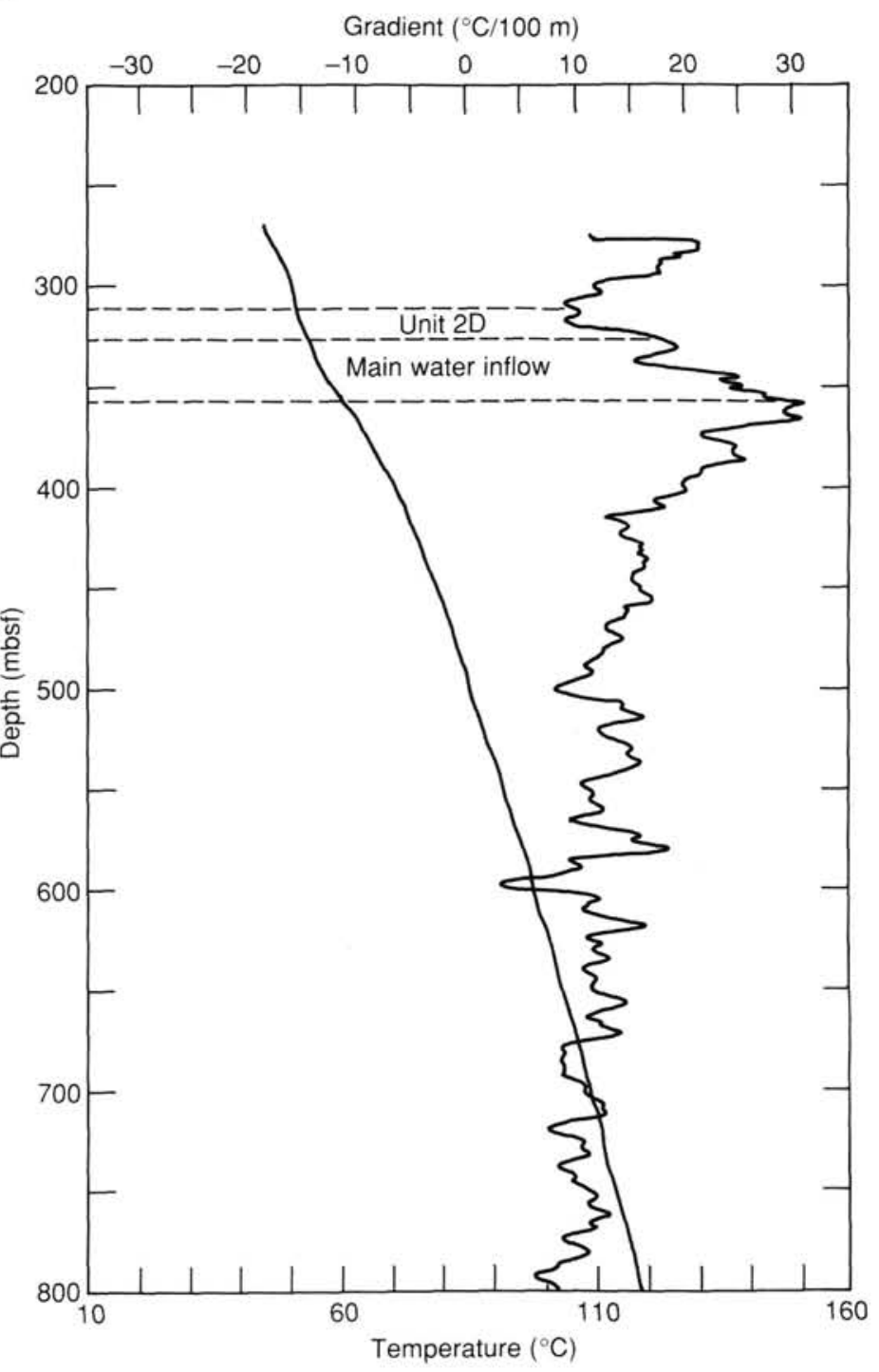

C

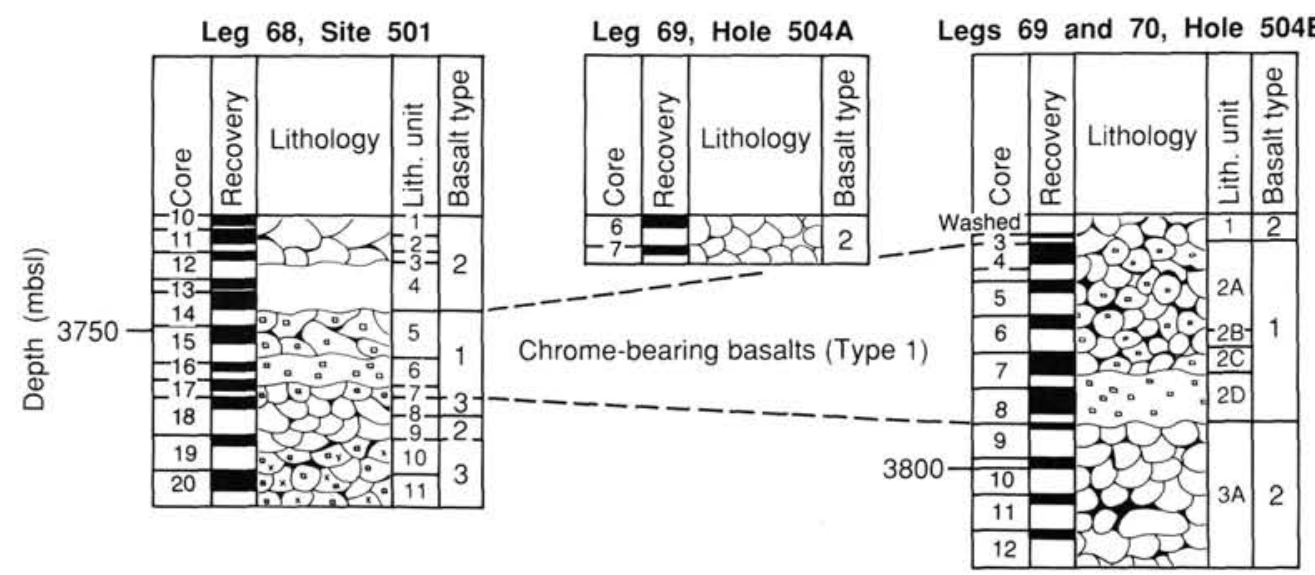

Figure 7. A. Temperature logs recorded in Hole 504B during Legs $69,70,83$, and 92. B. Temperature log and thermal gradient recorded in Hole 504B during Leg 111, with the location of Unit 2D. C. Compared lithologies in Holes 501, 504A, and 504B. 

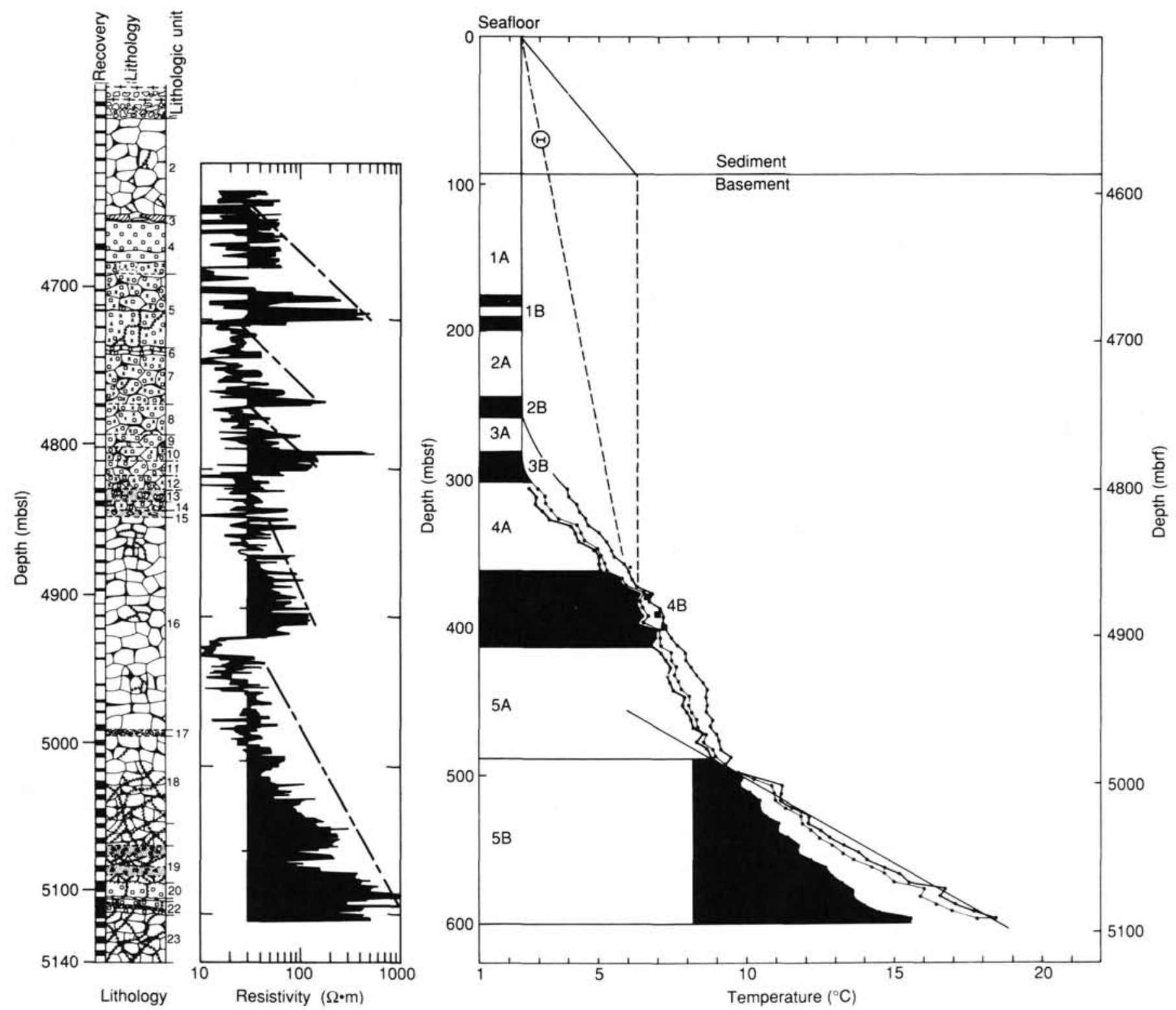

Figure 8. Lithology from core descriptions, electrical resistivity log, and temperature logs recorded in Hole 395A during Leg 78A. The dashed lines represent the interpreted magmatic cycles of Hyndman and Salisbury (1984). The shaded areas represent the sections of the crust with in-situ resistivities measured in excess of $30 \mathrm{ohm}-\mathrm{m}$.

Surprisingly, some of the total porosity of the small-to-medium size flows constitutes series with depth (Fig. 5B; Shipboard Scientific Party, 1988). These trends, visible as well on other logs used to derive porosity profiles (such as density, epithermal neutron, or compressional-wave velocity), build sequences in which the porosity is in some cases inversely related to unit thickness (4090 to 4150 mbrf; Fig. 5B). Such a sequence could reflect variations in flow energy, possibly linked to a decrease in the magma supply from a particular source. Consequently, it is necessary to check whether these units have been petrologically related and whether such systematics, if present, can be traced in the geochemical data. In contrast to these sequences, the massive units thicker than $10 \mathrm{~m}(3790,4055$, and 4155 mbrf; Fig. 5) do not have porosities related to other units and may therefore be interpreted as isolated magmatic events.

One of these thick flows (Unit 27) constitutes one of the most striking features of the porosity profile derived from resistivity data. This low-porosity unit $(0.05 \%)$ coincides with a ma- jor alteration boundary revealed by thin-section analysis (Alt and Emmermann, 1985; Emmermann, 1985; Alt et al., 1985, 1986) and confirmed by geochemical log data (Fig. 5C). Below this boundary, the most intensively altered zones (Fig. 5C) are confined to pillow sections located directly below massive units (4160, 4330, and $4380 \mathrm{mbsf})$. The high CEC measurements within these low-porosity units indicate that the entire crust was permeated by fluids and altered. As a consequence, the claycorrected porosity profile provides a better fit to core measurements (Fig. 5E) than the initial interpretation of Archie's law (Fig. 5B). An exception to the accuracy of this model is found in the Na-Ca zeolites zone (3995-4025 mbrf, or 520-550 mbsf) described by Alt et al. (1985), where the porosity is clearly underestimated with respect to core measurements. This discrepancy might originate in the mineralogical inversion derived from the geochemical log, where the low resistivity of zeolites is misinterpreted as high-resistivity smectites (Fig. 5C). This is likely because potassium enrichment within this zone is included in the 
mineralogy inversion as smectite, instead of the more appropriate potassium-rich zeolites. A more accurate porosity profile should therefore be obtained (1) from a more accurate mineralogical inversion and (2) by taking into account the temperature dependence of clays. Clay conduction was reported to be the dominant conduction mechanism in basalt at temperatures greater than $80^{\circ} \mathrm{C}$ (Olhoeft, 1981), and such a correction requires a series of laboratory experiments in order to relate CEC and activation energy for each major alteration facies (P. Pezard, unpubl. data). Such a correction should further reduce the porosity estimate from $4000 \mathrm{~m}$ downward, where temperatures higher than $80^{\circ} \mathrm{C}$ have been measured (Fig. 7A). This improved porosity estimate should help to eliminate the paradox of low permeability and high apparent porosity in Layer 2B (Becker, 1985).

\section{Transition Zone and Layer $2 C$}

The transition zone is shown on the DLL as a region of continuously increasing values of electrical resistivity toward values higher than $50 \mathrm{ohm}-\mathrm{m}$ in the dikes. The high-frequency character of the porosity profile in this zone reflects alternating sequences of intrusive and extrusive (more porous) units. In this zone, the total porosity decreases gradually with depth to become as low as a fraction of a percent at the top of Layer $2 \mathrm{C}$, and it remains as low to the bottom of the penetrated section (Figs. 5C and 5E). Another good correspondence is observed here between the computed values of porosity and the core measurements, once clay conduction is taken into account (Fig. 5E). The only important anomaly in this profile of otherwise constant resistivity occurs at the bottom of the hole (1497 mbsf), with a tight zone characterized by an increase of one order of magnitude in electrical resistivity values and where the slowest drilling of Leg 111 was recorded. At the top of the transition zone, the estimate of fracture porosity (Fig. 5B) is in good agreement with that observed in the cored breccias (Fig. 5). This correlation contrasts with a weaker correlation observed shallower in the hole, where the locations of intensely fractured basalt were obviously not sampled in the coring process.

\section{Morphology and Accretion of the Upper Oceanic Crust}

From the previous study of the resistivity-derived porosity profile, the penetrated section can be divided into four main zones, from the top of the basement down.

1. A 130 -m-thick zone of high porosity (averaging $7.0 \%$ ) has a large amount of fracturing, both horizontal and vertical in nature. This zone equates to the seismically defined Layer $2 \mathrm{~A}$.

2 . The underlying $400-\mathrm{m}$-thick zone of lower porosity (average $4.0 \%$ ) consists of flows and pillows and is equivalent to Layer $2 \mathrm{~B}$. The regime of mainly vertical fractures in this second zone might reflect the overall cooling of the lithosphere by hydrothermal fluids (Lister, 1972, 1974).

3. The transition zone from Layer $2 \mathrm{~B}$ to the sheeted dikes of Layer $2 \mathrm{C}$ begins at approximately $4280 \mathrm{mbrf}$ ( $806 \mathrm{mbsf}$ ) and terminates at 4620 mbrf (1146 mbsf).

4. In the zone below 4620 mbrf, the porosity decreases gradually to values as small as a fraction of a percent in the dikes $(0.1 \%)$, and the fracturing distribution is again mostly vertical.

The transition from dikes to pillows and flows was largely documented previously from ophiolite studies (Gass and Smewing, 1973; Kidd, 1977; Stern and Elthon, 1979). The contrast between the intrusive and the extrusive origin of these basalts is widely accepted as related to the way new oceanic crust is formed at mid-ocean ridges. On the other hand, the relation to the large-scale structure of the crust of the mineralized stockwork in the transition zone (4380-4400 mbrf, or 905-925 mbsf) is not yet understood. The location of this hydrological feature was proposed to be related to the mixing of cold, downgoing seawater with hot, already reacted fluids coming from the underlying dike section (Anderson et al., this volume). Similarly, no definite explanation has been given for the existence of the "seismically slow" Layer $2 \mathrm{~A}$, as opposed to a "faster" Layer $2 \mathrm{~B}$, although it was related to a possible zone of intense alteration of the basaltic crust after studies at DSDP Sites 417 and 418 (Donnelly, Francheteau, et al., 1980; Salisbury et al., 1980). Such a velocity decrease (to a value of 2.0 to $3.0 \mathrm{~km} / \mathrm{s}$ ) was noticed for a zone about $100 \mathrm{~m}$ thick within a few kilometers of the East Pacific Rise (E. Vera, pers. comm., 1988), which implies that Layer $2 \mathrm{~A}$ might be of morphological origin.

Based on the analysis of topographic profiles and seafloor images recorded on the Juan de Fuca Ridge, Kappel and Ryan (1986) discussed previous models of crustal accretion at medium- to fast-spreading mid-ocean ridges (Luyendyk and Macdonald, 1977; Spiess et al., 1980; Ballard et al., 1981; Francheteau, 1983; Macdonald, 1983) and proposed a non-steady-state model, by which excessive volcanism periodically builds a crestal ridge along the axis of seafloor spreading, with an elongated summit depression (ESD) typically observed in the spine of this crestal ridge. The variable dimensions of the ESD and the relation among flow morphologies have lead Kappel and Ryan (1986) to the following model of oceanic crustal accretion: (1) extrusive volcanic construction that widens the crestal ridge prior to the collapse of the summit depression, (2) collapse within the summit region of the crestal ridge to form an ESD during a phase of volcanic inactivity, and (3) renewed magmatism in the ESD as the floor widens by extension.

The crustal area studied by Kappel and Ryan (1986) in the active volcanic zone (from the axis of the ridge outward) equates in a way to the section sampled in Hole 504B from the bottom of Layer 2B upward. Large flood events, such as Unit 2D in Hole 504B, or similar features in other DSDP Holes 501, 505, 332 , or $395 \mathrm{~A}$, are usually observed on the seafloor to be associated with the presence of an ESD, as lavas extruded in massive quantities tend to fill this topographic low. If each massive flow found at shallow depth in the oceanic crust is associated with an ESD and if the volcanic construction was emplaced prior to the collapse of the ESD, it should be found on top of the previous volcanic construction in vertical cross section. Lava morphologies have been found to be dependent on temperature, viscosity, phenocryst content, or spreading rate at eruption (Bonatti and Harrisson, 1988), evolving from sheet flow to pillow lava as a volcanic construction develops and the magma source weakens. The upper part of such a construction should consequently consist mainly of fractured pillows and lava tubes (Hekinian et al., 1983; Hekinian, 1984). These weak structures are thus excellent candidates, after collapsing into the ESD and being capped by a 10 -m-thick flow, to give birth to the highly porous and heterogeneous structures like those found in Hole 504B (Anderson et al., 1985a). Such a model might mean that Layer $2 \mathrm{~A}$ might not be continuous away from the ridge axis and therefore may be laterally limited, as implied by the progressive filling of the reservoir observed since initial drilling (Becker et al., 1983; Becker, Sakai, et al., 1988). It implies, in addition, that some of the "slow" hydrothermal circulation, as opposed to the "fast" circulation related to the black smokers, might start close to the ridge axis, controlled by near-axis lava and seafloor morphologies. The associated alteration would therefore exist from the axis onward, allowing for higher temperatures of metamorphism at an early stage. In that respect, it is interesting to remember that the transition from low-temperature seawater alteration to suboxic/anoxic alteration at higher temperatures (Alt et al., 1985) was found exactly at the base of the second massive flow penetrated by drilling (the top of Unit 27 is located at 4060 mbrf, or 585 mbsf). Consequently, this example of morphological control on 
hydrothermal circulation might be thought of as the remains of an earlier ESD, below which horizontal fractures have been plugged entirely. Only a few vertical ones might remain open within this paleoreservoir, under stresses associated with the cooling of the oceanic lithosphere.

\section{CONCLUSIONS}

The measurement of deep and shallow resistivities allowed us to estimate total and fracture porosity in Hole 504B, the deepest borehole yet drilled into the oceanic crust. The resistivity and geochemical logs were used to define a 1200 -m-long porosity profile that permitted us (1) to discriminate the large-scale layers of the oceanic crust, (2) to discriminate individual lithologic units (such as pillow units and massive flows), and (3) to describe the overall morphology of the upper crust. In that respect, the two massive flows of lithologic Unit 2D, penetrated at about $50 \mathrm{~m}$ within basement, may be associated with the underlying high-porosity, underpressured aquifer that must have originated at the ridge axis, a location of intense hydrothermal circulation.

The fracture porosity can be related in most cases to thermal stresses coming from the direct cooling (1) of the unit or (2) of nearby extrusions or intrusions. The remaining fractures may be attributed to tectonic features such as the inferred listric fault at about 4300 mbrf (825 mbsf; Shipboard Scientific Party, 1988). The matrix porosity is constant for long sections of the hole and decreases by steps with depth. Exceptions to this general trend are found at 4000 mbrf, where a zone of resistive zeolites is represented by low apparent values of porosity. The extremely low value of porosity in the dikes indicates a slower regime of hydrothermal circulation deeper into the crust.

The comparison of the clay-corrected porosity profile to (1) the alteration of the basalts observed in thin sections and (2) the analysis of the geochemical logs indicates a strong correlation between alteration and morphology. Although it is difficult to know whether this observation is valid elsewhere in the oceanic crust, the lateral continuity of morphological features such as Layer $2 \mathrm{~A}$ or hydrological processes such as the underpressured reservoir might be checked with a series of closely spaced holes drilled perpendicular to the ridge axis.

\section{ACKNOWLEDGMENTS}

This work benefitted greatly from numerous discussions with Andrew Adamson, Jeff Alt, Keir Becker, Enrico Bonatti, Cristina Broglia, Robert Gable, Dan Moos, Roger Morin, Mike Mottl, and Bill Ryan and from careful reviews from Honor O'Malley, Malcolm Drury, and Mike Lovell. This work was supported by the NSF through JOI.

\section{REFERENCES}

Adamson, A. C., 1985. Basement lithostratigraphy, DSDP Hole 504B. In Anderson, R. N., Honnorez, J., Becker, K., et al., Init. Repts. $D S D P, 83$ : Washington (U.S. Govt. Printing Office), 121-127.

Alt, J. C., and Emmermann, R., 1985. Geochemistry of hydrothermally altered basalts: DSDP Hole 504B. In Anderson, R. N., Honnorez, J., Becker, K., et al., Init. Repts. DSDP, 83: Washington (U.S. Govt. Printing Office), 249-262.

Alt, J. C., Honnorez, J., Laverne, C., and Emmermann, R., 1986. Hydrothermal alteration of a 1-km section through the upper oceanic crust, DSDP Hole 504B: mineralogy, chemistry and evolution of seawater-basalt interactions. J. Geophys. Res., 91:309-335.

Alt, J. C., Laverne, C., and Muehlenbachs, K., 1985. Alteration of the upper oceanic crust: mineralogy and processes in DSDP Hole 504B, Leg 83. In Anderson, R. N., Honnorez, J., Becker, K., et al., Init. Repts. DSDP, 83: Washington (U.S. Govt. Print. Office), 217-248.

Anderson, R. N., Honnorez, J., Becker, K., et al., 1985. Init. Repts. DSDP, 83: Washington (U.S. Govt. Printing Office).

Anderson, R. N., O'Malley, H., and Newmark, R. L., 1985a. Use of geophysical logs for quantitative determination of fracturing, alteration, and lithostratigraphy in the upper oceanic crust, DSDP Holes 504B and 556. In Anderson, R. N., Honnorez, J., Becker, K., et al.,
Init. Repts. DSDP, 83: Washington (U.S. Govt. Printing Office), 443-478.

Anderson, R. N., and Zoback, M. D., 1982. Permeability, underpressures, and convection in the oceanic crust near the Costa Rica Rift. J. Geophys. Res., 87:2860-2868.

Anderson, R. N., Zoback, M. D., Hickman, S. H., and Newmark, R. L., 1985b. Permeability versus depth in the upper oceanic crust: in situ measurements in DSDP Hole 504B, eastern equatorial Pacific. J. Geophys. Res., 90:3659-3669.

Archie, G. E., 1942. The electrical resistivity log as an aid in determining some reservoir characteristics. J. Pet. Technol., 5:1-8.

Ballard, R. D., Francheteau, J., Juteau, T., Rangin, C., and Normark, W., 1981. East Pacific Rise at $21^{\circ} \mathrm{N}$ : the volcanic, tectonic, and hydrothermal processes of the central axis. Earth Planet. Sci. Lett., 55:1-10.

Becker, K., 1985. Large-scale electrical resistivity and bulk porosity of the oceanic crust, DSDP Hole 504B, Costa Rica Rift. In Anderson, R. N., Honnorez, J., Becker, K., et al., Init. Repts. DSDP, 83: Washington (U.S. Govt. Printing Office), 419-427.

Becker, K., Langseth, M. G., Von Herzen, R. P., and Anderson, R. N., 1983. Deep crustal geothermal measurements, Hole 504B, Costa Rica Rift. J. Geophys. Res., 88:3347-3457.

Becker, K., Sakai, H., et al., 1988. Proc. ODP, Init. Repts., 111: College Station, TX (Ocean Drilling Program).

Bonatti, E., and Harrisson, C.G.A., 1988. Eruption styles of basalt in oceanic spreading ridges and seamounts: effect of magma temperature and viscosity. J. Geophys. Res., 93:2967-2980.

Boyeldieu, C., and Martin, C., 1984. Fracture detection and evaluation [paper 21 presented at the SPWLA 9th European Formation Evaluation Symposium, London].

Boyeldieu, C., and Winchester, A., 1982. Use of the dual laterolog for the evaluation of the fracture porosity in hard carbonate formations [paper presented at the Offshore Southeast Asia Conference, Singapore].

Brace, W. F., and Orange, A. S., 1968a. Further studies of the effect of pressure on the electrical resistivity of rocks. J. Geophys. Res., 73: $5407-5420$.

1968b. Electrical resistivity changes in saturated rocks during fracture and frictional sliding. J. Geophys. Res., 73:1433-1445.

Brace, W. F., Orange, A. S., and Madden, T. R., 1965. The effect of pressure on the electrical resistivity of water-saturated crystalline rocks. J. Geophys. Res., 70:5669-5678.

Broglia, C., and Ellis, D. V., 1988. Response of the thermal neutron porosity log to alteration and environmental factors in basaltic rocks from ODP sites. EOS, Trans. Am. Geophys. Union, 69:1403. (Abstract)

Broglia, C., and Moos, D., 1988. In-situ structure and properties of $110-$ Ma crust from geophysical logs in DSDP Hole 418A. In Salisbury, M. H., Scott, J. H., et al., Proc. ODP, Sci. Results, 102: College Station, TX (Ocean Drilling Program), 29-47.

Cann, J. R., Langseth, M. G., Honnorez, J., Von Herzen, R. P., White, S. M., et al., 1983. Init. Repts. DSDP, 69: Washington (U.S. Govt. Printing Office).

Cann, J. R., and Von Herzen, R. P., 1983. Downhole logs at DSDP Sites 501, 504, and 505, near the Costa Rica Rift. In Cann, J. R., Langseth, M. G., Honnorez, J., Von Herzen, R. P., White, S. M., et al., Init. Repts. DSDP, 69: Washington (U.S. Govt. Printing Office), 281-300.

Christensen, N. I., and Salisbury, M. H., 1985. Seismic velocities, densities, and porosities of Layer $2 \mathrm{~B}$ and Layer $2 \mathrm{C}$ basalts from Hole 504B. In Anderson, R. N., Honnorez, J., Becker, K., et al., Init. Repts. DSDP, 83: Washington (U.S. Govt. Printing Office), 367370.

Clavier, C., Coates, G., and Dumanoir, J., 1977. The theoretical and experimental bases for the dual-water model for the interpretation of shaly sands [paper 6859 presented at the SPE 52nd Annual Technical Conference, Denver, $\mathrm{CO}$.

Cox, C. S., 1971. The electrical conductivity of the oceanic lithosphere. In The Structure and Physical Properties of the Earth's Crust: Washington (Am. Geophys. Union), 227-234.

Cox, C. S., Constable, S. C., Chave, A. D., and Webb, S. C., 1986. Controlled-source electromagnetic sounding of the oceanic lithosphere. Nature, 320:53-54.

Costa Rica Rift United Scientific Team (CRRUST), 1982. Geothermal regimes of the Costa Rica Rift, East Pacific, investigated by drilling, 
DSDP-IPOD Legs 68, 69, and 70. Geol. Soc. Am. Bull., 93:862887.

Detrick, R., Honnorez, J., Bryan, W. B., Juteau, T., et al., 1988. Proc. ODP, Init. Repts., 106/109: College Station, TX (Ocean Drilling Program).

Donnelly, T., Francheteau, J., Bryan, W., Robinson, P., Flower, M., Salisbury, M., et al., 1980. Init. Repts. DSDP, 51, 52, 53: Washington (U.S. Govt. Printing Office).

Drury, M. J., and Hyndman, R. D., 1979. The electrical resistivity of oceanic basalts. J. Geophys. Res., 84:4537-4546.

Ellis, D. V., 1987. Well Logging for Earth Scientists: New York (Elsevier).

Emmermann, R., 1985. Basement geochemistry, Hole 504B. In Anderson, R. N., Honnorez, J., Becker, K., et al., Init. Repts. DSDP, 83: Washington (U.S. Govt. Printing Office), 183-199.

Francheteau, J., 1983. The oceanic crust. Sci. Am., 249:114-129.

Gass, I. G., and Smewing, J. D., 1973. Intrusion, extrusion, and metamorphism at constructive margins: evidence from the Troodos Massif, Cyprus. Nature, 242:26-29.

Hekinian, R., 1984. Undersea volcanoes. Sci. Am., 251:46-55.

Hekinian, R., Renard, V., and Cheminee, J. L., 1983. Hydrothermal deposits on the East Pacific Rise near $13^{\circ} \mathrm{N}$ : geological setting and distribution of active sulfide chimneys. In Rona, et al., Hydrothermal Processes at Sea Floor Spreading Centers: 117-127.

Hermance, J. F., 1979. The electrical conductivity of materials containing partial melt: a simple model from Archie's law. Geophys. Res. Lett., 6:613-616.

Herron, M., 1986. Subsurface geochemistry: future applications of geochemical data [paper presented at IAEA meeting on Nuclear Data for Applied Nuclear Geophysics, Vienna, Austria].

Hill, H. J., and Milburn, J. D., 1956. Effect of clay and water salinity on the electrochemical behavior of reservoir rocks. Trans. Am. Inst. Mine., Metall. Pet. Eng., 207:

Hobart, M. A., Langseth, M. G., and Anderson, R. N., 1985. A geophysical and geothermal survey on the south flank of the Costa Rica Rift: Sites 504 and 505. In Anderson, R. N., Honnorez, J., Becker, K., et al., Init. Repts. DSDP, 83: Washington (U.S. Govt. Printing Office), 379-404.

Houtz, R., and Ewing, J., 1976. Upper crustal structure as a function of plate age. J. Geophys. Res., 81:2490-2498.

Hyndman, R. D., and Salisbury, M. H., 1984. The physical nature of the oceanic crust on the Mid-Atlantic Ridge, DSDP Hole 395A. In Hyndman, R. D., Salisbury, M. H., et al., Init. Repts. DSDP, 78B: Washington (U.S. Govt. Printing Office), 839-848.

Jackson, P. D., Taylor Smith, D., and Stanford, P. N., 1978. Resistivityporosity-particle shape relationships for marine sands. Geophysics, 43:1250-1268.

Kappel, E. S., and Ryan, W.B.F., 1986. Volcanic episodicity and a nonsteady state rift valley along northeast Pacific spreading centers: evidence from Sea MARC I. J. Geophys. Res., 91:925-940.

Karato, S. I., 1985. Physical properties of basalts from DSDP Hole 504B, Costa Rica Rift. In Anderson, R. N., Honnorez, J., Becker, K., et al., Init. Repts. DSDP, 83: Washington (U.S. Govt. Printing Office), 687-695.

Kidd, R.G.W., 1977. A model for the process of formation of the upper oceanic crust. Geophys. J. R. Astron. Soc., 50:149-183.

Kirkpatrick, R. J., 1979. The physical state of the oceanic crust: results of downhole geophysical logging in the Mid-Atlantic Ridge at $23^{\circ} \mathrm{N}$. J. Geophys. Res., 84:178-188.

Kirsch, G., 1898. Die theorie der elastizitaet und die beduerfnisseder festigkeitslehre. VDI Z, 29:797-807.

Lister, C.R.B., 1972. On the thermal balance of a mid-ocean ridge. Geophys. J. R. Astron. Soc., 26:515-535.

1974. On the penetration of water into hot rock. Geophys. $J$ R. Astron. Soc., 39:465-509.

Lonsdale, R., and Klitgord, K. D., 1978. Structure and tectonic history of the eastern Panama Basin. Geol. Soc. Am. Bull., 89:981-999.

Lovell, M. A., 1985. Thermal conductivity and permeability assessment by electrical resistivity measurements in marine sediments. Mar. Geotech., 6:205-240.

Luyendyk, B. P., and Macdonald, K. C., 1977. Physiography and structure of the inner floor of the FAMOUS Rift Valley: observations with a deep-towed instrument package. Geol. Soc. Am. Bull., 88: 648-663.
Macdonald, K. C., 1983. Crustal processes at spreading centers. Rev. Geophys. Space Phys., 21:1441-1454.

Melson, W. G., Rabinowitz, P. D., et al., 1979. Init. Repts. DSDP, 45: Washington (U.S. Govt. Printing Office).

Mottl, M. J., Anderson, R. N., Jenkins, R. N., and Lawrence, J. R., 1983. Chemistry of waters sampled from basaltic basement in DSDP Holes 501, 504B, and 505B. In Cann, J. R., Langseth, M. G., Honnorez, J., Von Herzen, R. P., White, S. M., et al., Init. Repts. DSDP, 69: Washington (U.S. Govt. Printing Office), 475-483.

Newmark, R. L., Anderson, R. N., Moos, D., and Zoback, M. D., 1985. Sonic and ultrasonic logging of Hole 504B and its implications for the structure, porosity, and stress regime of the upper $1 \mathrm{~km}$ of the oceanic crust. In Anderson, R. N., Honnorez, J., Becker, K., et al., Init. Repts. DSDP, 83: Washington (U.S. Govt. Printing Office), 479-510.

Olhoeft, G. R., 1981. Electrical properties of rocks. In Touloukian, Y. S., Judd, W. R., and Roy, R. F. (Eds.), Physical Properties of Rocks and Minerals: New York (McGraw-Hill), 257-330.

Pape, H., Riape, L., and Schopper, J. R., 1985. Petrophysical detection of microfissures in granites. Trans. SPWLA Annu. Logging Symp., 25:Pap. P.

Pape, H., and Worthington, P. F., 1983. A surface-structure model for the electrical conductivity of reservoir rocks [paper presented at the SPWLA 8th European Formation Evaluation Symposium, London].

Ral, C. S., and Manghnani, M. H., 1981. The effect of saturant salinity and pressure on the electrical resistivity of Hawaiian basalts. Geophys. J. R. Astron. Soc., 65:395-405.

Rink, M., and Schapper, J. R., 1974. Interface conductivity and its implications to electric logging. Trans. SPWLA Annu. Logging Symp., 15:Pap. J.

Salisbury, M. H., Donnelly, T. W., and Francheteau, J., 1980. Geophysical logging in DSDP Hole 417D. In Donnelly, T., Francheteau, J., Bryan, W., Robinson, P., Flower, M., Salisbury, M., et al., Init. Repts. DSDP, 51, 52, 53: Washington (U.S. Govt. Printing Office), 705-713.

Serra, O., 1984. Fundamentals of Well-Log Interpretation: Amsterdam (Elsevier).

Shankland, T. J., and Waff, H. S., 1977. Partial melting and electrical conductivity anomalies in the upper mantle. J. Geophys. Res., 82: 5409-5417.

Shipboard Scientific Party, 1988. Site 504: Costa Rica Rift. In Becker, K., Sakai, H., et al., Proc. ODP, Init. Repts., 111: College Station, TX (Ocean Drilling Program), 35-251.

Sibbit, A. M., and Faivre, O., 1985. The dual laterolog response in fractured rock. Trans. SPWLA Annu. Logging Symp., 26:Pap. T.

Spiess, F. N., Macdonald, K. C., Atwater, T., Ballard, R. D., Carranza, A., Cordoba, D., Cox, C. S., Diaz Garcia, V. M., Francheteau, J., Guerrero, J., Hawkins, J., Haymon, R., Hessler, R., Juteau, T., Kastner, M., Larson, R., Luyendyk, B., Macdougall, J. D., Miller, S., Normark, W., Orcutt, J., and Rangin, C., 1980. East Pacific Rise: hot springs and geophysical experiments. Science, 207:14211432.

Stern, C., and Elthon, D., 1979. Vertical variations in the effects of hydrothermal metamorphism in Chilean ophiolites: their implications for ocean floor metamorphism. Tectonophysics, 55:179-213.

Waff, H. S., 1974. Theoretical considerations of electrical conductivity in a partially molten mantle and implications for geothermometry. $J$. Geophys. Res., 79:4003-4010.

Waxman, M. H., and Smits, L.J.M., 1968. Electrical conductivities in oil-bearing shaly sands. Trans. Am. Inst. Mine., Metall. Pet. Eng., 243:

Winsauer, W. O., and McCardell, W. M., 1953. Ionic double-layer conductivity in reservoir rocks. Trans. Am. Inst. Mine., Metall. Pet. Eng., 198:129-134.

Worthington, P., 1985. The evolution of shaly-sand concepts in reservoir evaluation. Log Analyst, Jan-Feb.

Young, P. D., and Cox, C. S., 1981. Electromagnetic active source sounding near the East Pacific Rise. Geophys. Res. Lett., 8:10431046.

Date of initial receipt: 19 October 1988

Date of acceptance: 3 March 1989

Ms 111B-139 